\title{
Decadal biogeochemical changes in the subtropical Indian Ocean associated with Subantarctic Mode Water
}

\author{
M. Álvarez, ${ }^{1}$ T. Tanhua, ${ }^{2}$ H. Brix,${ }^{3}$ C. Lo Monaco, ${ }^{4}$ N. Metzl, ${ }^{4}$ E. L. McDonagh, ${ }^{5}$ \\ and H. L. Bryden ${ }^{5}$ \\ Received 23 June 2010; revised 1 June 2011; accepted 21 June 2011; published 17 September 2011.
}

[1] Within the Subantarctic Mode Water (SAMW) density level, we study temporal changes in salinity, nutrients, oxygen and TTD (Transit Time Distribution) ages in the western (W) and eastern (E) subtropical gyre of the Indian Ocean (IO) from 1987 to 2002. Additionally, changes in Total Alkalinity (TA) and Dissolved Inorganic Carbon (DIC) are evaluated between 1995 and 2002. The mechanisms behind the detected changes are discussed along with the results from a hindcast model run (Community Climate System Model). The increasing salinity and decreasing oxygen trends from 1960 to 1987 reversed from 1987 to 2002 along the gyre. In the W-IO a decreasing trend in TTD ages points to a faster delivery of SAMW, thus less biogenic matter remineralization, explaining the oxygen increase and noisier nutrients decrease. In the E-IO SAMW, no change in TTD ages was detected, therefore the trends in oxygen and inorganic nutrients relate to changes in the Antarctic Surface Water transported into the E-IO SAMW formation area. In the W-IO between 1995 and 2002, the DIC increase is equal or even less than the anthropogenic input as the reduction in remineralization contributes to mask the increasing trend. In the E-IO between 1995 and 2002, DIC decreases slightly despite the increase in the anthropogenic input. Differences in the preformed E-IO SAMW conditions would explain this behavior. Trends in the W and E IO SAMW are decoupled and related to different forcing mechanisms in the two main sites of SAMW formation in the IO, at $40^{\circ} \mathrm{S}-70^{\circ} \mathrm{E}$ and $45^{\circ} \mathrm{S}-90^{\circ} \mathrm{E}$, respectively.

Citation: Álvarez, M., T. Tanhua, H. Brix, C. Lo Monaco, N. Metzl, E. L. McDonagh, and H. L. Bryden (2011), Decadal biogeochemical changes in the subtropical Indian Ocean associated with Subantarctic Mode Water, J. Geophys. Res., 116, C09016, doi:10.1029/2010JC006475.

\section{Introduction}

[2] Intermediate waters are prone to be affected by interannual physical and biogeochemical changes as they are directly ventilated from the surface and therefore are able to directly respond to anthropogenic and climate change. Several studies have observed changes in the temperature and salinity content of these waters in different regions of the ocean (see review by Bindoff et al. [2007]) but fewer have studied biogeochemical changes, mainly concentrating on dissolved oxygen [Bindoff et al., 2007] and anthropogenic carbon (see review by Sabine and Tanhua [2010]).

[3] Dissolved oxygen in the ocean is very sensitive, even more than any other physical or biogeochemical parameter,

\footnotetext{
${ }^{1}$ Instituto Español de Oceanografía, A Coruña, Spain.

${ }^{2}$ IFM-GEOMAR, Kiel, Germany.

${ }^{3}$ Department of Atmospheric and Oceanic Sciences, University of California, Los Angeles, California, USA.

${ }^{4}$ LOCEAN/IPSL, Université Paris 6, Paris, France. UK.

${ }^{5}$ NOCS, University of Southampton, Waterfront Campus, Southampton,

Copyright 2011 by the American Geophysical Union. 0148-0227/11/2010JC006475
}

to the balance between the supply though circulation and ventilation and the consumption due to respiratory processes. Oxygen changes could have important consequences for ecosystems and coastal economies and have consequently been proposed as a suitable indicator of climate change, analogous to a canary in the coal mine [Joos et al., 2003; Körtzinger et al., 2006]. Additionally, oxygen measurements, even those from historical data, generally have high precision and accuracy, making oxygen a target tracer on large-scale observing programs to detect decadal changes [Gruber et al., 2007].

[4] Changes in oxygen concentration have been detected in the North [e.g., Andreev and Kusakabe, 2001; Andreev and Watanabe, 2002; Emerson et al., 2001, 2004; Ono et al., 2001; Mecking et al., 2006; Whitney et al., 2007; Watanabe et al., 2001] and South [Schaffer et al., 2000] Pacific, the North Atlantic [Garcia et al., 1998; Johnson and Gruber, 2007], the Indian [Bindoff and McDougall, 2000; McDonagh et al., 2005] and the Southern [Matear et al., 2000] Oceans. Expansion and intensification of the oxygen minimum zones in the tropical Pacific and Atlantic have recently been reported [Stramma et al., 2008, 2009].

[5] Except for the air-sea exchange, nutrients are affected by the same physical and biological processes as oxygen. 
Consequently, their temporal trends can potentially be used to infer changes in marine biology affecting the carbon cycle. However, few studies report decadal changes in inorganic nutrient concentrations, mainly in the North Pacific [Bindoff et al., 2007]. Usually, measurement inaccuracies lead to contradicting results even when using the same database [Pahlow and Riebesell, 2000; Li and Peng, 2002; Gruber et al., 2000; Zhang et al., 2000].

[6] The detection and evaluation of changes in the ocean carbon system is one of the main objectives of the CLIVAR/ $\mathrm{CO}_{2}$ Repeat Hydrography Program and the GO-SHIP initiative. The ocean carbon system response to global climate change is a key issue if we are to predict the future ocean carbon sink and the processes controlling it. While much of the literature deals with the increase in the regional anthropogenic carbon load, especially in the North Atlantic Ocean [Sabine and Tanhua, 2010], fewer studies dealt with the decadal evolution of Dissolved Inorganic Carbon (DIC) separating human and climate induced perturbations. In the Pacific Ocean Sabine et al. [2008] evaluated the changes in DIC due to biology/physics and anthropogenic $\mathrm{CO}_{2}$ uptake concluding that factors beyond the latter can have a measurable impact on the decadal carbon distribution.

[7] Subantarctic Mode Water (SAMW) is a mode water mass observed in all of the Southern hemisphere subtropical gyres, formed by deep mixing in winter on the equatorward side of the subantarctic front [McCartney, 1977, 1982]. SAMW is identified by a potential vorticity minimum and a monotonic decrease of temperature and salinity with depth between approximately 150 and about 1150 dbars or the salinity minimum corresponding to Antarctic Intermediate Water (AAIW).

[8] The southern boundary of the Indian Ocean has been identified as a high signal-to-noise region for detecting climate change [Banks and Wood, 2002]. Previous studies have ascertained thermohaline and oxygen changes in the South Indian Ocean SAMW [Bindoff and McDougall, 2000; McDonagh et al., 2005] and model simulations assign at least the thermohaline changes to anthropogenic forcing [Banks et al., 2000], while more recent work attributes the changes to internal variability [Bryden et al., 2003; Murray et al., 2007; Stark et al., 2006]. SAMW has been identified as the main conduit of nutrients from the Southern Ocean to the rest of the ocean, accounting for about three-quarters of the biological production north of $30^{\circ} \mathrm{S}$ [Sarmiento et al., 2004]. Consequently, biogeochemical changes in this mode water could have significant consequences for biological productivity and, hence, the global carbon cycle.

[9] Oxygen is generally decreasing in the upper ocean (see review by Emerson et al. [2004] and Keeling et al. [2010]). On the contrary, recent findings for the Indian Ocean detect an oxygen increase in SAMW [McDonagh et al., 2005] from 1987 onwards. This observation was attributed to a faster ventilation, i.e., mode waters are delivered faster from their ventilation site to the western Indian Ocean at $32^{\circ} \mathrm{S}$ as concluded by McDonagh et al. [2005] from indirectly derived water mass ages or from geostrophic transports [Palmer et al., 2004]. Another possibility is a reduction in the biological pump rates or efficiency. It is, however, difficult to separate biological from physical forc- ing on biogeochemical changes [Keeling and Garcia, 2002].

[10] The study by McDonagh et al. [2005] focuses on the decadal thermohaline changes in SAMW along $32^{\circ} \mathrm{S}$, and concludes that the thermocline in the western Indian Ocean along $32^{\circ} \mathrm{S}$ is occupied by a single variety of mode water with a potential temperature around $13^{\circ} \mathrm{C}$, i.e., SAMW, formed near $40^{\circ} \mathrm{S} 70^{\circ} \mathrm{E}$ is of subtropical origin. On the eastern end the thermocline is occupied by mode water with a range of properties that cool from $11^{\circ} \mathrm{C}$ at $80^{\circ} \mathrm{E}$ to $9^{\circ} \mathrm{C}$ near Australia. These mode waters form over a range of ventilation sites, with the warmest mode formed around $90^{\circ} \mathrm{E}$. The salinity of the upper thermocline along $32^{\circ} \mathrm{S}$ in the Indian Ocean has increased from 1987 to 2002, reversing the trend found by Bindoff and McDougall [2000] before 1987. However, changes at the eastern end of the section are decoupled from those at the western IO: The upper thermocline in the western IO shows a progressive increase in salinity from 1987 to 1995 and 2002; this variability can be attributed to variations in the air-sea forcing at the formation site. In the eastern IO, the salinity increase mainly occurred between 1987 and 1995, with insignificant thermohaline changes between 1995 and 2002. This differential variability is attributed to changes in the equatorward Ekman flux of Antarctic surface waters into the formation site [McDonagh et al., 2005].

[11] In this work we assess changes in dissolved oxygen, inorganic nutrients, inorganic carbon, alkalinity and chlorofluorocarbon-derived (age and anthropogenic carbon) properties in the southern parts of the western and eastern Indian Ocean (W-IO and E-IO, respectively, hereinafter). We focus on the thermocline in the SAMW layer using data from sections sampled in 1987, 1995 and 2002, nominally along $32^{\circ} \mathrm{S}$, and we will try to elucidate the mechanisms behind those changes. We support our analyses by comparing the data to results from a hindcast model run performed with the ocean component of the NCAR CCSM climate model [Smith and Gent, 2004] coupled to a multifunctional group ocean biogeochemistry model [Moore et al., 2004; Doney et al., 2006]. The model's circulation and tracer fields are employed to support our analysis of possible causes of the observed temporal changes.

\section{Data Sets}

[12] Physical and chemical data from three repeat sections at the nominal latitude of $32^{\circ} \mathrm{S}$ from Africa to Australia were used in this study: November-December 1987 [Toole and Warren, 1993], March-April 1995, WOCE section I5E [Talley and Baringer, 1997], and June-July 1995, WOCE section I5W [Donohue and Toole, 2003]; and March-April 2002 [Bryden et al., 2003] (Figure 1). Carbon dioxide data were only measured for the 1995 and 2002 cruises, but all three of them provided chlorofluorocarbons (CFC). For the 1987 and 1995 cruises, we used the consistency-controlled data in GLODAP [Key et al., 2004]. The 2002 data set was checked for internal consistency in the physical, biogeochemical and tracer data as part of the CARINA synthesis effort [Lo Monaco et al., 2010]: Silicate and nitrate data were multiplied by a factor of 0.98 . The same analysis was applied to the 1987 and 1995 GLODAP data. Phosphate 


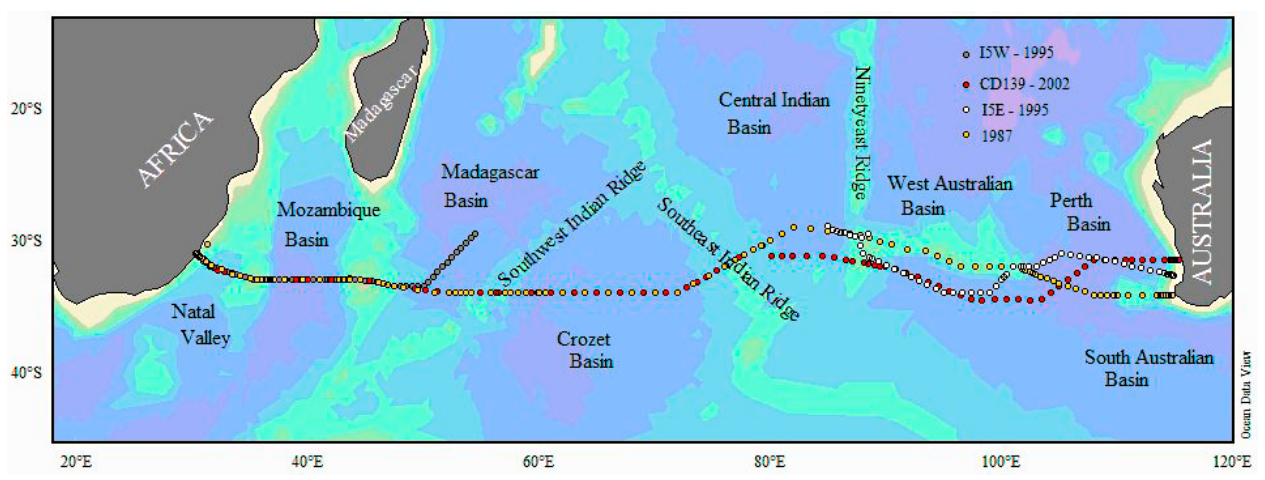

Figure 1. Positions of the stations used in this study for the CD139 (2002), I5E and I5W (1995) and I5 (1987) cruises.

data from the 1987 cruise was multiplied by a factor of 0.98 . The calculated inorganic carbon from the 2002 data set was reduced by $4 \mu \mathrm{mol} \mathrm{kg}^{-1}$ [Álvarez et al., 2009].

\section{Methods}

[13] Temporal changes will be studied within the permanent thermocline corresponding to SAMW, which is comprised below the seasonal mixed layer and the salinity minimum associated with Antarctic Intermediate Water (Figure 2). Looking at the stability parameter the SAMW layer is comprised between $120 \pm 56 \mathrm{dbar}$ and $1093 \pm 109 \mathrm{dbar}$ [McDonagh et al., 2005]. Sections of potential temperature, salinity, apparent oxygen utilization (AOU) and salinitynormalized dissolved inorganic carbon (NDIC) in the upper 1500 dbars for the 2002 data are shown in Figure 2. SAMW would be comprised between the neutral density layers $(\gamma) 26.4$ and 27.4 where the potential temperature salinity diagram practically presents a linear relation. SAMW is also identified with a Potential Vorticity minimum (not shown) which broadly follows the $13^{\circ} \mathrm{C}$ isotherm (Figure 2a) between $40^{\circ}$ and $70^{\circ} \mathrm{E}$ and east of $80^{\circ} \mathrm{E}$, is cooler between $11^{\circ}$ and $9^{\circ} \mathrm{C}$ [McDonagh et al., 2005]. SAMW decreases in salinity eastward, AOU and NDIC (Figures 2c and 2d) mainly present a vertical variability where SAMW has a low AOU and NDIC contrasting with the high values of both properties in the AAIW layer just below.

[14] According to McDonagh et al. [2005] temporal changes in W-IO SAMW would be quantified on potential temperature spaces. Changes in these mode waters are not isopycnal. Consequently, any physical or biogeochemical difference calculated using isopycnals as a reference will be exaggerated. At the E-IO SAMW, changes are densitycompensating. Therefore, density can be used as a reference. Note, however, that the same conclusions about the sequence of changes in salinity can be drawn for different ways to calculate the change: isopycnal, minimum difference, or changes on potential temperature surfaces [McDonagh et al., 2005]. Hence, for the sake of simplicity and in order to compare our results with previous and forthcoming interdisciplinary studies, we preferably use neutral density surfaces $(\gamma)$ as a reference for both the east and west IO.

[15] Using bottle data, vertical profiles are interpolated onto $\gamma$ levels every 0.02 units from 26.2 to $27.3 \mathrm{~kg} \mathrm{~m}^{-3}$ and are then horizontally interpolated from $40^{\circ} \mathrm{E}$ to $55^{\circ} \mathrm{E}$ every $0.2^{\circ}$. Differences on these $\gamma$-longitude fields are calculated between 2002 and 1995, 1995-1987 and 2002-1987. West of about $40^{\circ} \mathrm{E}$ there is a higher influence of Red Sea Water and also of recirculating Subtropical Mode Water mixed with the $13^{\circ} \mathrm{C}$ mode water. Therefore, water west of $40^{\circ} \mathrm{E}$ is not representative of the recently ventilated thermocline [McDonagh et al. 2005] and it is not taken into account. The Mean Difference Profile (MDP) and Standard Deviation Difference Profile (SDDP) weighted by the number of grid points are calculated from the subtracted $\gamma$-longitude fields between $40^{\circ} \mathrm{E}$ and $55^{\circ} \mathrm{E}$. The same procedure is applied to the E-IO data, from $85^{\circ} \mathrm{E}$ to the Australian coast (around $115^{\circ} \mathrm{E}$ ) (Figures 3 and 4 ). For a given density and time interval, the MDP values are averaged and weighted by the SDDP, so we calculate the WMD and the WMSD, i.e., the Weighted Mean Difference and the Weighted Mean Standard Deviation (Table 2) for the studied variables.

[16] We have investigated the temporal changes in salinity (S) and compared our results with those from McDonagh et al. [2005] to check our methods. The chemical variables studied were Apparent Oxygen Utilization (AOU), nitrate $\left(\mathrm{NO}_{3}\right)$, phosphate $\left(\mathrm{PO}_{4}\right)$, silicate $\left(\mathrm{SiO}_{2}\right)$, total alkalinity (TA) and dissolved inorganic carbon (DIC). We also included estimated variables, in particular the DIC changes due to decomposition of soft and hard biogenic matter ( $\mathrm{DIC}^{\mathrm{Bio}}$ ), anthropogenic carbon $\left(\mathrm{C}_{\mathrm{ANT}}\right)$ and $\mathrm{CFC}-12$ mean ages from a Transit Time Distribution (TTD) method.

[17] Total DIC changes between two periods of time can be ascribed to: i) a biological component, i.e., due to any variation in the decomposition of soft and hard tissue biogenic matter $\left(\mathrm{DIC}^{\mathrm{Bio}}\right)$; ii) the $\mathrm{C}_{\mathrm{ANT}}$ uptake by the ocean (DIC $^{\mathrm{CANT}}$ ); and iii) DIC variations due to physical processes in DIC not correlated with AOU, as changes in the air-sea exchange, air-sea disequilibrium, ocean circulation, mixing and ventilation (DIC $\left.{ }^{\text {Phys }}\right)$ :

$$
\Delta \mathrm{DIC}=\Delta \mathrm{DIC}^{\mathrm{Bio}}+\Delta \mathrm{DIC}^{\mathrm{CANT}}+\Delta \mathrm{DIC}^{\mathrm{Phys}} .
$$

[18] The first three terms of equation (1) are calculated as explained below, while the $\Delta D C^{\text {Phys }}$ is derived as a difference. This equation assumes a one-end-member pipe flow with no diapycnal mixing. 


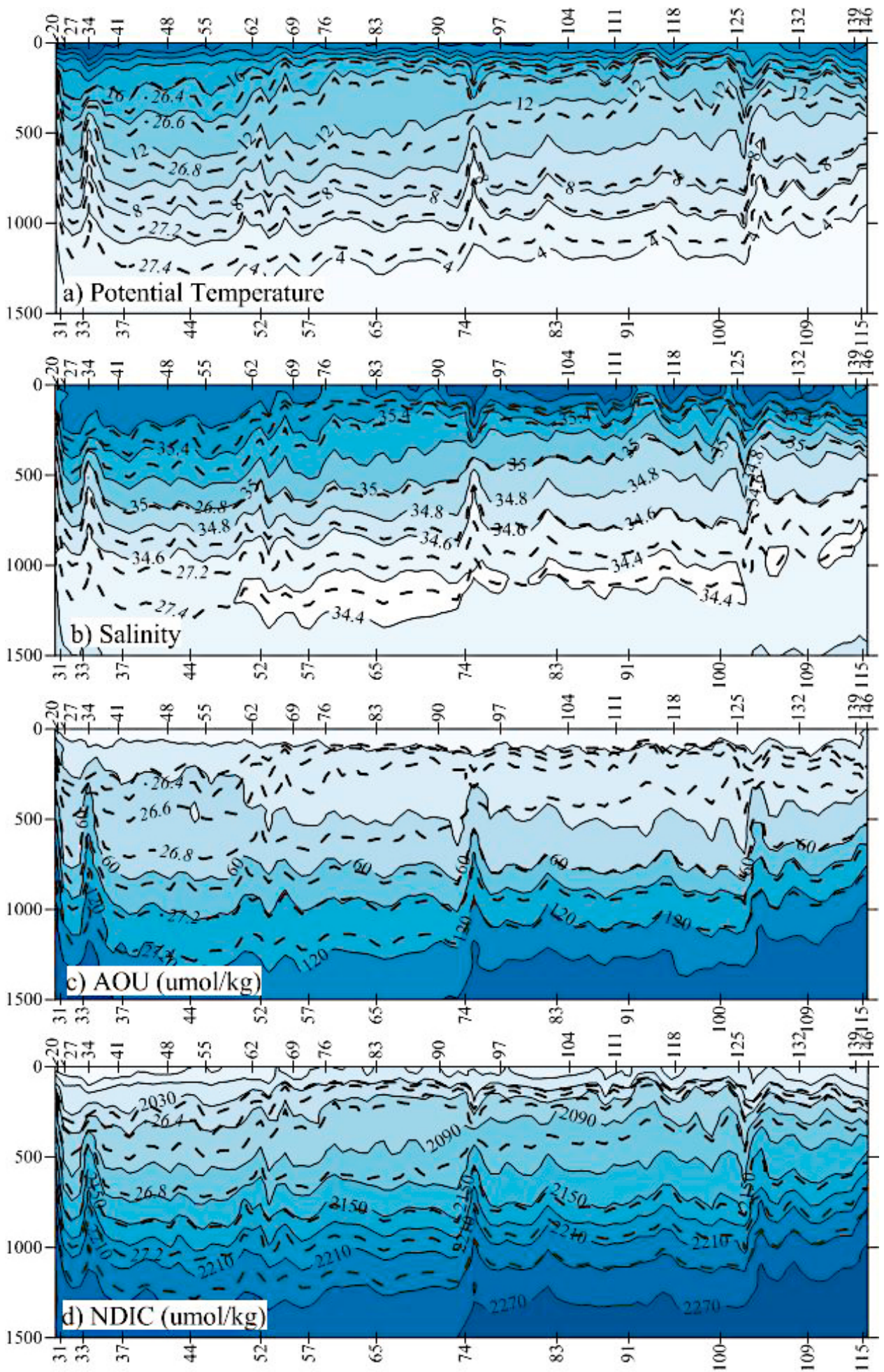

Figure 2. Vertical distribution of (a) potential temperature $\left({ }^{\circ} \mathrm{C}\right.$ ), (b) salinity, (c) Apparent Oxygen Utilization $\left(\mu \mathrm{mol} \mathrm{kg}{ }^{-1}\right)$ and (d) salinity normalized Dissolved Inorganic Carbon $\left(\mu \mathrm{mol} \mathrm{kg}^{-1}\right)$ along the 2002 CD139 section. The upper axis shows station positions and the lower axis longitude. 

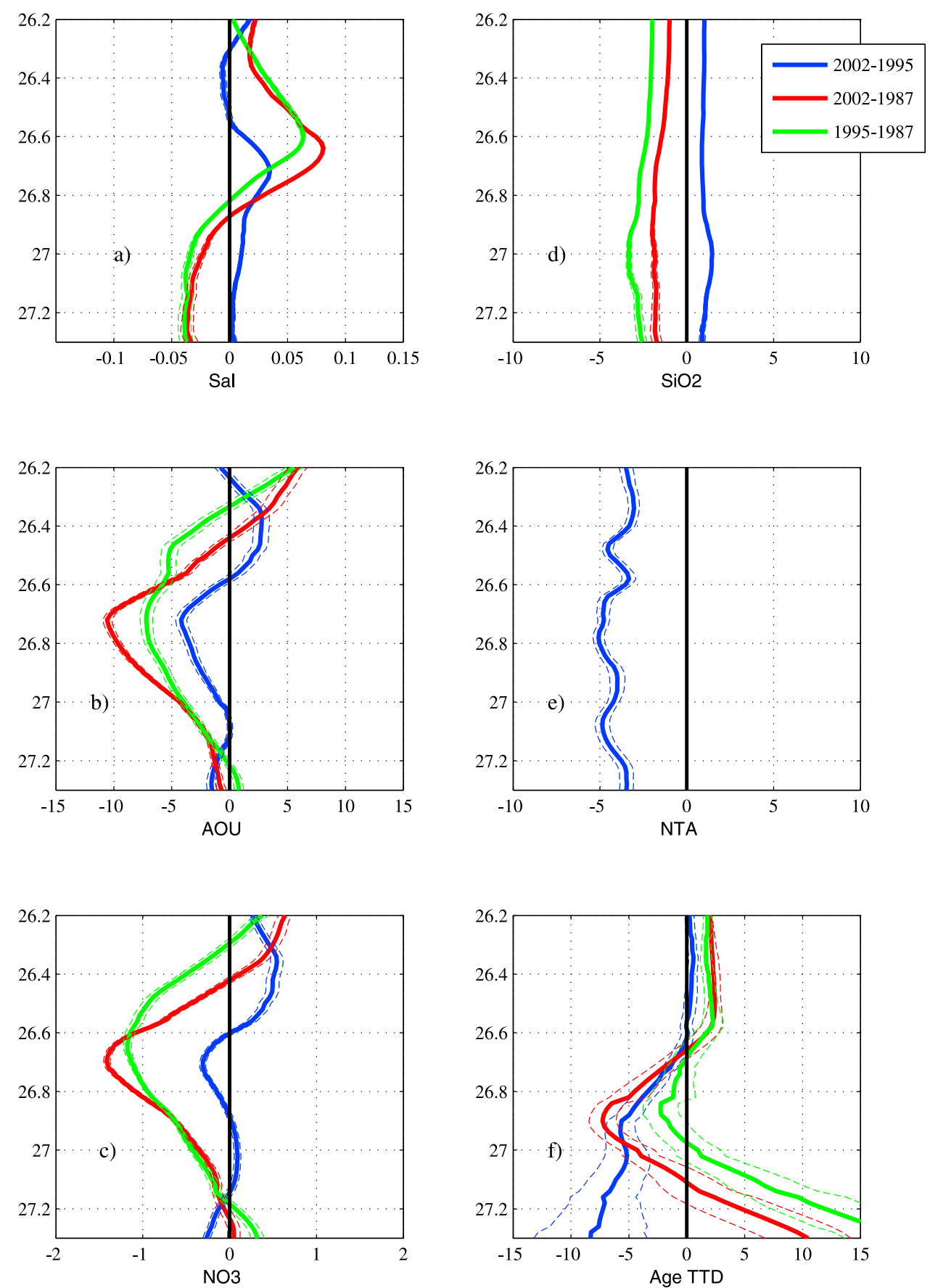

Figure 3. MDP (Mean Difference Profile, solid lines) and SDDP (Standard Deviation Difference Profiles, dotted lines) salinity, biogeochemical $\left(\mu \mathrm{mol} \mathrm{kg}^{-1}\right)$ and TTD age (years) changes for the Western IO $\left(40^{\circ} \mathrm{E}-55^{\circ} \mathrm{E}\right)$ between 1987 and 2002 (red), 1987 and 1995 (green) and 1995 and 2002 (dark blue). Changes are calculated on neutral density surfaces. Changes are for the later year minus the earlier year, so a positive salinity difference indicates a salinity increase over the time period.

[19] Total DIC changes ( $\triangle$ DIC) between 2002 and 1995 are calculated directly from data. DIC ${ }^{\mathrm{Bio}}$ is calculated for the 1995 and 2002 cruises according to the following equation:

$$
\begin{aligned}
\mathrm{DIC}^{\mathrm{Bio}} & =\mathrm{AOU} / \mathrm{R}_{\mathrm{C}}+{ }^{1} / 2 \cdot\left(\mathrm{TA}-\mathrm{TA}^{0}+\mathrm{AOU} / \mathrm{R}_{\mathrm{N}}\right) \\
& =0.8 \cdot \mathrm{AOU}+{ }^{1} / 2 \cdot\left(\mathrm{TA}-\mathrm{TA}^{0}\right)
\end{aligned}
$$

where AOU is oxygen saturation [Benson and Krause, 1984] minus measured oxygen $\left(\mathrm{O}_{2}\right)$, TA ${ }^{0}$ is preformed TA and, $\mathrm{R}_{\mathrm{C}}$ and $\mathrm{R}_{\mathrm{N}}$ are stoichiometric ratios $\mathrm{C} / \mathrm{O}_{2}$ and $\mathrm{N} / \mathrm{O}_{2}$ according to Körtzinger et al. [2001]. $\mathrm{TA}^{0}$ was calculated according to Lo Monaco et al. [2005].

[20] In order to estimate $\triangle \mathrm{DIC}^{\mathrm{CANT}}$ two different approaches can be followed: i) estimate the bulk $\mathrm{C}_{\mathrm{ANT}}$ values for 

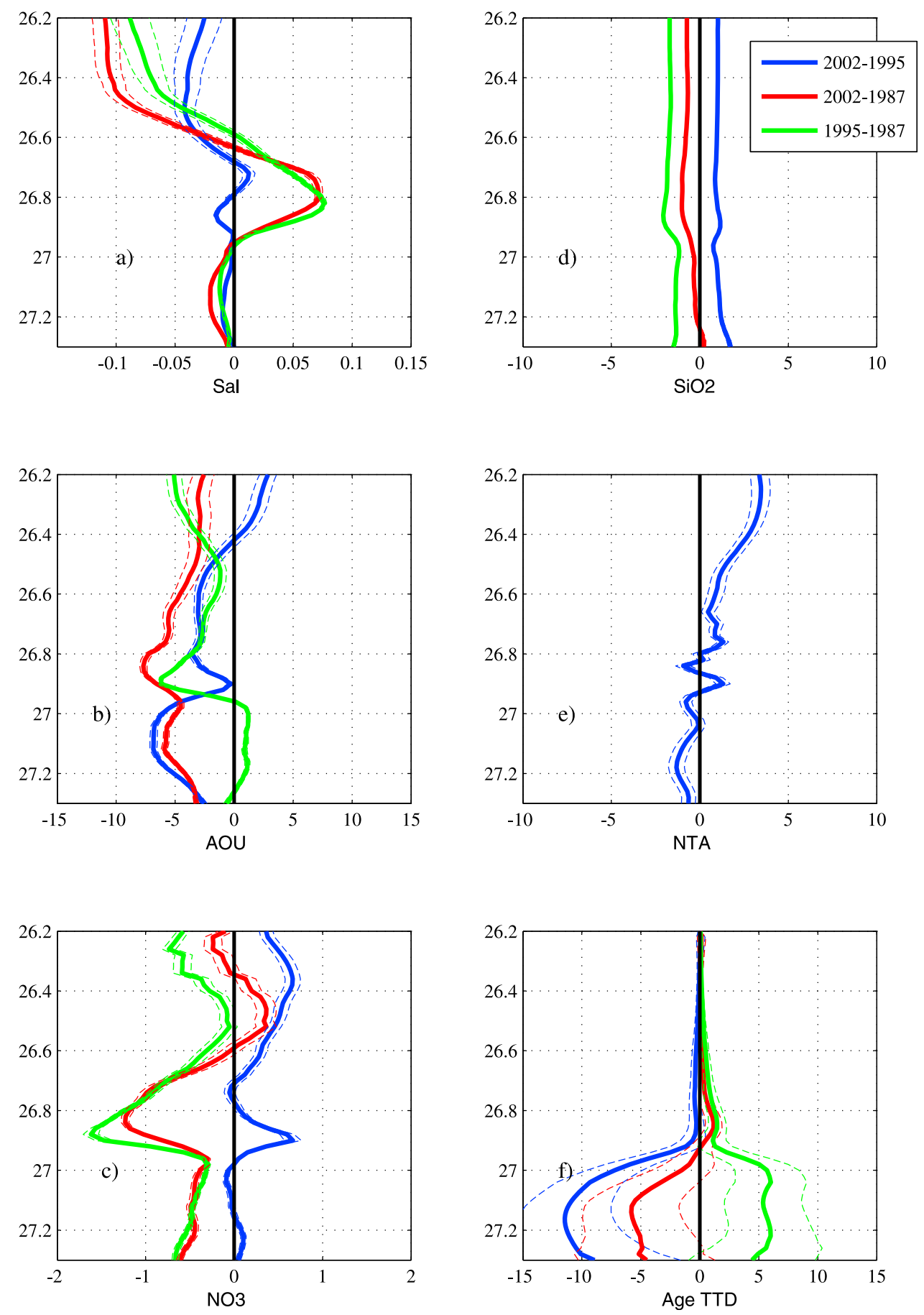

Figure 4. MDP (Mean Difference Profile, solid lines) and SDDP (Standard Deviation Difference Profiles, dotted lines) salinity, biogeochemical $\left(\mu \mathrm{mol} \mathrm{kg}{ }^{-1}\right)$ and TTD age (years) changes for the Eastern IO $\left(82^{\circ} \mathrm{E}-115^{\circ} \mathrm{E}\right.$ ) between 1987 and 2002 (red), 1987 and 1995 (green) and 1995 and 2002 (dark blue). Changes are calculated on neutral density surfaces. Changes are for the later year minus the earlier year, so a positive salinity difference indicates a salinity increase over the time period.

each time period using a databased method and study the temporal evolution on $\gamma$ coordinates; or ii) calculate the $\mathrm{C}_{\mathrm{ANT}}$ increase between the two periods of time using for example an MLR (Multiple Linear Regression) approach and finally study this unique variable on $\gamma$ coordinates. Here, we tried both as a check for the different $\mathrm{C}_{\mathrm{ANT}}$ methods.
[21] $\mathrm{C}_{\mathrm{ANT}}$ and ages were estimated for the three data sets using the TTD approach, which have been shown to provide reliable $C_{A N T}$ estimates for the SAMW layer in the subtropical Indian Ocean [Álvarez et al., 2009]. We used CFC-12 data to determine the TTD of each water sample applying the time-dependent saturation described by Tanhua et al. 
Table 1. Regression Coefficients for the MLRs Used to Quantify the DIC Change Between 1995 and 2002 with Equation (3) for the Eastern and Western $\mathrm{IO}^{\mathrm{a}}$

\begin{tabular}{lccccccccc}
\hline Cruise & Intercept & $\mathrm{S}$ & $\mathrm{TA}$ & $\mathrm{NO}_{3}$ & $\mathrm{SiO}_{2}$ & $\mathrm{AOU}$ & $\mathrm{R}$ & $\mathrm{R}^{2}$ & $\mathrm{Error}(\mathrm{n})$ \\
\hline $\mathrm{E}-1995$ & $1275 \pm 527$ & $-3.4 \pm 11$ & $0.02 \pm 0.06$ & $0.45 \pm 0.68$ & $0.98 \pm 0.22$ & $0.34 \pm 0.08$ & $33 \pm 8$ & 0.993 & $4.92(232)$ \\
$\mathrm{E}-2002$ & $-613 \pm 381$ & $-34.2 \pm 8.3$ & $0.94 \pm 0.12$ & $1.13 \pm 0.49$ & $-0.25 \pm 0.22$ & $0.26 \pm 0.07$ & $65 \pm 7$ & 0.992 & $6.53(285)$ \\
$\mathrm{W}-1995$ & $1091 \pm 761$ & $1.28 \pm 21.5$ & $-0.01 \pm 0.09$ & $0.84 \pm 2.06$ & $0.94 \pm 0.43$ & $0.29 \pm 0.21$ & $36 \pm 12$ & 0.995 & $4.41(131)$ \\
W-2002 & $-735 \pm 569$ & $-7.56 \pm 13.9$ & $0.94 \pm 0.19$ & $4.07 \pm 0.88$ & $-0.52 \pm 0.32$ & $0.06 \pm 0.09$ & $33 \pm 7$ & 0.996 & $3.1(183)$ \\
\hline
\end{tabular}

${ }^{\text {a }}$ The regression coefficient $\left(\mathrm{R}^{2}\right)$, the number of samples (n), and the standard error of the adjustment are also given.

[2008], assuming an air-sea carbon disequilibrium not changing during the last few hundred years and an equal relationship between the mean age $(\Gamma)$ and the width of the $\operatorname{TTD}(\Delta)$. This had been found to be a realistic assumption of the relation between advective and diffusive transport in the Ocean [Waugh et al., 2004, 2006; Tanhua et al., 2008].

[22] The TTD $\mathrm{C}_{\mathrm{ANT}}$ estimation yields absolute values while the eMLR method calculates the temporal increase. The so-called "extended" MLR (eMLR) method for $\mathrm{C}_{\mathrm{ANT}}$ estimates of Friis et al. [2005] uses multiple linear regressions of dissolved inorganic carbon on repeated measurements of inorganic carbon and related hydrochemical properties. The coefficients of the two regressions are subtracted resulting in a new multivariate equation that predicts the differences in DIC between the two data sets that are not correlated with temporal changes of the underlying hydrochemical parameters. The interpretation is that natural variability of DIC between the two data sets is compensated via the regression on hydrochemical parameters that are known to influence DIC whereas the remaining "unexplained" differences relate to changes in $\mathrm{C}_{\mathrm{ANT}}\left(\triangle \mathrm{DIC} \mathrm{CANT}^{\mathrm{CAN}}\right.$-eMLR) between the two surveys.

[23] $\triangle \mathrm{DIC} \mathrm{CANT}^{\mathrm{CAN}}$-eMLR was calculated with the "forward" case, the subtracted coefficients were applied on the modern data set:

$$
\begin{aligned}
\Delta \mathrm{DIC}^{\mathrm{CANT}}-\mathrm{eMLR}= & \left(\mathrm{a}_{2}-\mathrm{a}_{1}\right) \cdot \mathrm{S}_{2}+\left(\mathrm{b}_{2}-\mathrm{b}_{1}\right) \cdot \mathrm{TA}_{2}+\left(\mathrm{c}_{2}-\mathrm{c}_{1}\right) \\
& \cdot \mathrm{NO}_{32}+\left(\mathrm{d}_{2}-\mathrm{d}_{1}\right) \cdot \mathrm{SiO}_{22}+\left(\mathrm{e}_{2}-\mathrm{e}_{1}\right) \\
& \cdot \mathrm{AOU}_{2}+\left(\mathrm{f}_{2}-\mathrm{f}_{1}\right) \cdot \gamma_{2}+\left(\mathrm{g}_{2}-\mathrm{g}_{1}\right)
\end{aligned}
$$

where the regression coefficients are specified in Table 1 for the East and West IO, the subscripts 1 and 2 stand for the 1995 and 2002 data sets, respectively, for data $26.2>\gamma>27.3$, east of $40^{\circ} \mathrm{E}$ in the case of the W-IO and the whole E-IO.

[24] The forward case was selected after a random error analysis following Tanhua et al. [2007]. Briefly, simulated anthropogenic DIC increases $\left(\triangle D I C{ }^{s i m}\right)$ were introduced into the inorganic carbon 2002 and 1995 data, this $\triangle D C^{\text {sim }}$ was compared with that predicted with the eMLR method, using the initial DIC data as the historic cruise and the modified one as the modern cruise. Two hundred regression lines were calculated after introducing random noise (twice the analytical error) into the hydrochemical input data. After the 200 perturbations, the mean and STD of the difference between the DIC increase predicted with the eMLR and that predicted with $\triangle \mathrm{DIC}^{\mathrm{sim}}$, were always lower when the analysis was performed for the 2002 data set.

\section{Model Description}

[25] The ocean physical component of the Community Climate System Model (CCSM3.1) is based on the Los
Alamos National Laboratory Parallel Ocean Program (POP) [Smith and Gent, 2004]. In this version the grid is symmetric in the Southern Hemisphere with a zonal resolution of $3.6^{\circ}$; meridional resolution decreases from $1.8^{\circ}$ at midlatitudes to about $0.8^{\circ}$ at high and low latitudes. The surface layer is $12 \mathrm{~m}$ thick; there are in total 5 layers to $111 \mathrm{~m}$, and 25 layers to the bottom. This model also invokes Gent-McWilliams isopycnal mixing and bolus transport scheme [Gent and McWilliams, 1990] and the nonlocal K-profile parameterization (KPP) upper ocean model [Large et al., 1994]. The sea-ice component resides on the same grid as the ocean and treats both thermodynamics and sea-ice advection [Briegleb et al., 2004].

[26] The physical model component is coupled to the ecological-biogeochemical multiFunctional Group Model (FGM), which utilizes a state of the art, marine ecosystem module [Moore et al., 2004] linked with an ocean biogeochemistry module [Doney et al., 2006, 2009a] with full carbonate system thermodynamics. The ecosystem module incorporates multinutrient limitation (inorganic nutrients and iron) and specific phytoplankton functional groups into a traditional phytoplankton-zooplankton-detritus-nutrient food web. The ecosystem is linked with an ocean biogeochemistry module based on an expanded version of the OCMIP biotic model [Doney et al., 2004]. Prognostic variables are added for DIC, TA and $\mathrm{O}_{2}$. The full carbonate system thermodynamics allow for computation of surface water partial pressure of $\mathrm{CO}_{2}$ and air-sea $\mathrm{CO}_{2}\left(\right.$ and $\left.\mathrm{O}_{2}\right)$ [Doney et al., 2009b] transfer using a quadratic wind speed formulation [Wanninkhof, 1992] and NCEP 10-m winds.

[27] Two model runs are performed with the CCSM-FGM for the years 1958-2004: One being forced with anthropogenic (or historical) atmospheric $\mathrm{CO}_{2}$ values and one that uses a fixed pre-industrial value of $278 \mathrm{ppm}$. We concentrate our analysis on oxygen/AOU variability on the time span between 1980 and 2004, calculating the anomalies from the mean of this period. We decompose the AOU anomalies $(\triangle \mathrm{AOU})$ into two terms:

$$
\Delta \mathrm{AOU}=\Delta \mathrm{AOU}^{\mathrm{Bio}}+\Delta \mathrm{AOU}^{\text {Phys }}
$$

where any anthropogenic term is excluded from this equation by applying our analysis to the pre-industrial run. The biologically driven component is estimated from $\mathrm{PO}_{4}$ changes $\left(\triangle \mathrm{AOU}^{\mathrm{Bio}}=\mathrm{r}_{\mathrm{O} 2: \mathrm{PO} 4} \cdot \Delta \mathrm{PO}_{4}\right)$ assuming a constant stoichiometric $\mathrm{O}_{2}: \mathrm{PO}_{4}$ ratio $\left(\mathrm{r}_{\mathrm{O} 2: \mathrm{PO}}\right)$ of -170 , and the physical term, $\triangle \mathrm{AOU}^{\mathrm{Phys}}$, is calculated as the remainder of the two other terms.

\section{Results and Discussion}

[28] Both the $\gamma$-longitude distribution (not shown) and the MDP (Figures 3a and 4a) W-IO and E-IO temporal salinity 
Table 2. Weighted Mean Difference and Weighted Mean Standard Deviation for the Temporal Changes in Salinity, Biogeochemistry, and TTD Age in Figure 3 for the W-IO, Figure 4 for the E-IO, and Figure 7 for DIC in Both Parts

\begin{tabular}{|c|c|c|c|c|c|c|}
\hline & \multicolumn{3}{|c|}{$\mathrm{W}-\mathrm{IO}$} & \multicolumn{3}{|c|}{ E-IO } \\
\hline & $2002-1987$ & 1995-1987 & $2002-1995$ & $2002-1987$ & 1995-1987 & $2002-1995$ \\
\hline $\mathrm{S}^{\mathrm{a}}$ & $0.070 \pm 0.002$ & $0.053 \pm 0.002$ & $0.020 \pm 0.002$ & $0.052 \pm 0.002$ & $0.064 \pm 0.002$ & $-0.009 \pm 0.002$ \\
\hline $\mathrm{AOU}^{\mathrm{b}}$ & $-9.73 \pm 0.36$ & $-6.90 \pm 0.50$ & $-3.59 \pm 0.46$ & $-6.08 \pm 0.27$ & $-2.42 \pm 0.19$ & $-3.20 \pm 0.27$ \\
\hline $\mathrm{NO}_{3}$ & $-1.24 \pm 0.04$ & $-1.00 \pm 0.03$ & $-0.21 \pm 0.03$ & $-0.70 \pm 0.04$ & $-0.75 \pm 0.04$ & $0.12 \pm 0.03$ \\
\hline $\mathrm{PO}_{4}$ & $-0.09 \pm 0.01$ & $-0.08 \pm 0.01$ & $-0.01 \pm 0.01$ & $0.00 \pm 0.01^{\mathrm{c}}$ & $-0.02 \pm 0.01$ & $0.02 \pm 0.01$ \\
\hline $\mathrm{SiO}_{2}$ & $-1.80 \pm 0.07$ & $-2.67 \pm 0.04$ & $0.91 \pm 0.06$ & $-0.80 \pm 0.04$ & $-1.76 \pm 0.04$ & $0.98 \pm 0.04$ \\
\hline TA & & & $-3.5 \pm 0.3$ & & & $-0.5 \pm 0.3^{\mathrm{c}}$ \\
\hline NTA & & & $-4.9 \pm 0.3$ & & & $-0.1 \pm 0.4^{\mathrm{c}}$ \\
\hline DIC & & & $4.1 \pm 0.5$ & & & $-1.0 \pm 0.2$ \\
\hline NDIC & & & $3.0 \pm 0.6$ & & & $-0.7 \pm 0.2$ \\
\hline $\mathrm{DIC}^{\mathrm{Bio}}$ & & & $-4.4 \pm 0.6$ & & & $-2.8 \pm 0.3$ \\
\hline $\mathrm{C}_{\mathrm{ANT}} \mathrm{TTD}$ & $12.9 \pm 0.6$ & $6.3 \pm 0.7$ & $6.5 \pm 0.4$ & $11.0 \pm 0.6$ & $4.9 \pm 0.6$ & $6.1 \pm 0.5$ \\
\hline $\mathrm{C}_{\mathrm{ANT}}$ eMLR & & & $5.4 \pm 0.1$ & & & $-0.9 \pm 0.1$ \\
\hline $\mathrm{Age}^{\mathrm{d}}$ & $-6.3 \pm 1.3$ & $-1.3 \pm 1.7^{\mathrm{c}}$ & $-4.7 \pm 1.2$ & $0.7 \pm 0.8^{\mathrm{c}}$ & $1.5 \pm 0.9^{\mathrm{c}}$ & $-0.7 \pm 0.7^{\mathrm{c}}$ \\
\hline
\end{tabular}

${ }^{\mathrm{a}}$ Salinity changes were calculated for the W-IO between $\gamma$ 26.5-26.7 and for the E-IO between $\gamma$ 26.7-26.9.

${ }^{\mathrm{b}}$ Biogeochemical changes were calculated for the W-IO between $\gamma 26.65-26.85$ and for the E-IO between $\gamma 26.8-27$. All biogeochemical changes are measured in $\mu \mathrm{mol} \mathrm{kg}{ }^{-1}$.

${ }^{\mathrm{c}}$ No significant change. The signal-to-noise ratio (SNR $\left.=\mathrm{WMD} / \mathrm{WMSD}\right)$ is lower than 1.96 , T-student with two tails value for large samples with a 0.05 level of significance.

${ }^{\mathrm{d}}$ TTD age changes (measured in years) were calculated for the W-IO between $\gamma 26.8-27$ and for the E-IO between $\gamma 26.8-27$.

differences are consistent with the results by McDonagh et al. [2005] obtained after CTD data, which give us confidence in our results obtained using bottle data.

\subsection{Western Indian Ocean}

[29] Within the W-IO thermocline maximum salinity changes occurred in the early period (1987-1995) between 26.5 and 26.7 corresponding to $12.5-13.5^{\circ} \mathrm{C}$ (Figure 3a). These changes are ascribed to altered air-sea fluxes in the formation area with a higher net heat flux causing a salinity increase on isothermal surfaces [McDonagh et al., 2005].

[30] The strongest changes in $\mathrm{AOU}, \mathrm{NO}_{3}$ (Figures $3 \mathrm{~b}$ and $3 \mathrm{c}$ ) and $\mathrm{PO}_{4}$ (not shown) were found at slightly higher densities in the thermocline, $26.65-26.85$, or $10-12^{\circ} \mathrm{C}$. No clear extreme was found for $\mathrm{SiO}_{2}$ (Figure 3d) and NTA (normalized TA) (Figure 3e). AOU and $\mathrm{NO}_{3}$ were decreasing with time for both periods (i.e., the oxygen concentrations were increasing) (Figures $3 \mathrm{~b}$ and $3 \mathrm{c}$ ) in coherence with the salinity increase (Figure 3a), unlike $\mathrm{SiO}_{2}$ (Figure 3d). Table 2 shows the WMD and WMSD in the 26.65-26.85 $\gamma$ range. $\mathrm{NO}_{3}$ changes are consistent (and practically Redfieldian) with the AOU changes. This is not the case for $\mathrm{PO}_{4}$. Although the nutrient data were corrected to be consistent within the three data sets, identifying and correcting for nutrient offsets is a difficult task [e.g., Lo Monaco et al., 2010] because international reference materials were not used.

[31] After losing contact with the atmosphere, the primary mechanism for changing $\mathrm{AOU}$ is the decomposition of organic matter which depends on the amount of organic matter to be decomposed and the elapsed time since the water left the surface mixed layer, assuming a constant decomposition rate. There are two possible and mutually not exclusive mechanisms to explain the AOU decrease or oxygen increase: i) an acceleration of the circulation and/or ii) a decrease in the organic matter input. Either way, the amount of organic matter decomposed reduces, and there will be a commensurate change in the carbon and nutrient inventory associated with the AOU change.
[32] The oxygen increase, i.e., AOU decrease, in the W-IO thermocline can be related to an increase in the SAMW ventilation [McDonagh et al., 2005]. The hypothesis of an accelerating gyre circulation is supported by the TTD age decrease from 1987 to 1995 to 2002 (Figure 3f), however, the oxygen changes are regular from 1987 onwards (Figure $3 b$ ). The TTD mean age of the SAMW between the neutral densities 26.8-27 varies between 7 and 10 years, consequently if the SAMW formation site has not moved the subtropical gyre has sped up by $50-70 \%$. Our results are qualitatively consistent with McDonagh et al. [2005], although we obtained stronger gyre acceleration.

[33] The accuracy commonly accepted for TA measurements is $6 \mu \mathrm{mol} \mathrm{kg}^{-1}$ [Tanhua et al., 2010]. Therefore, the detected NTA decrease between 1995 and 2002 of $4.9 \pm$ $0.3 \mu \mathrm{mol} \mathrm{kg}{ }^{-1}$ (Figure 3e and Table 2) can be disregarded. However, alkalinity measurements for the W-IO in 1995 and 2002 were done against Certified Reference Material. Additionally, no discrepancy was found for TA values in the North Atlantic Deep Water core in the Mozambique Basin $(-2 \pm$ $5 \mu \mathrm{mol} \mathrm{kg}{ }^{-1}$ [Álvarez et al., 2009]). Despite the salinity and $\mathrm{C}_{\mathrm{ANT}}$ increase, processes that could drive a TA increase, two other processes can serve to explain the thermocline alkalinity decrease: i) an increase in organic matter remineralization or ii) a reduction of carbonate dissolution. These processes are both related to the amount of biological material involved (export production from the upper layer) and the time this material has to decompose (gyre speed). The fact that AOU decreases excludes point (i), while the increase in the gyre speed would be equivalent to a reduction in organic matter remineralization (increasing TA) and a reduction in carbonate dissolution (decreasing TA). The fact that TA decreases hints to this last point being stronger than the increase in TA due to a reduction in organic matter remineralization. Our result is in contrast to the alkalinity increase by $8.3 \mu \mathrm{mol} \mathrm{kg}^{-1}\left(\sigma_{\theta}=26.8\right)$ between GEOSECS (1974) and WOCE (1994) detected by Sarma et al. [2002] in the northern Indian Ocean explained by a $\mathrm{pH}$ reduction 

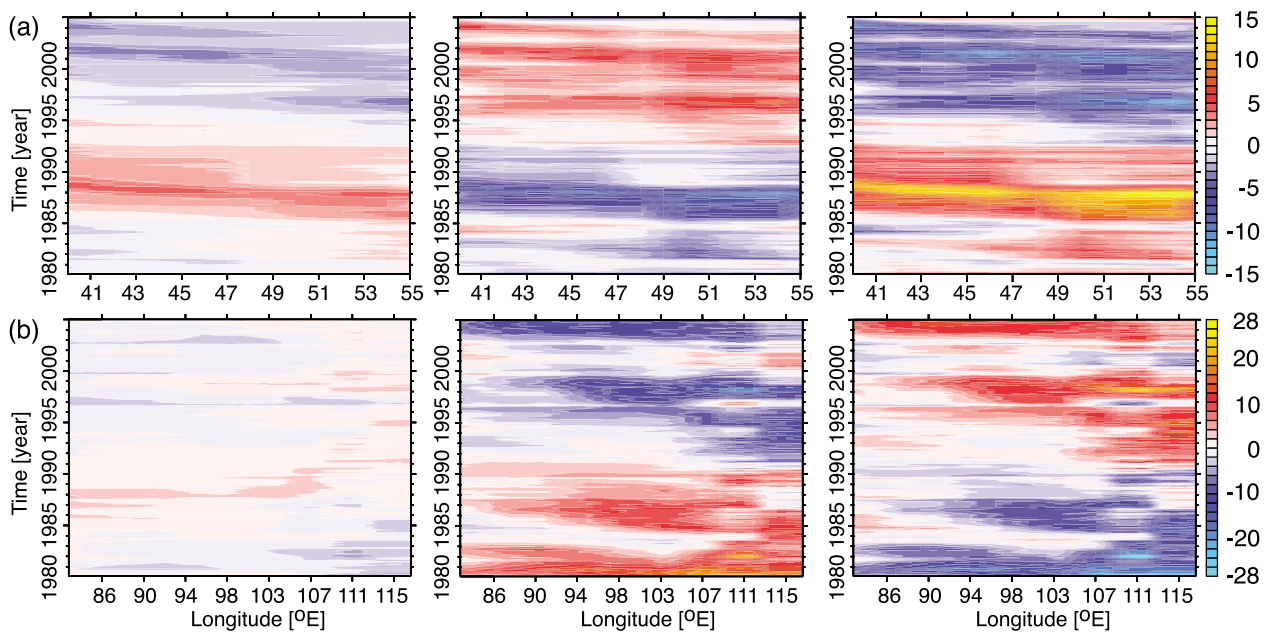

Figure 5. Hovmoeller diagrams for the components of equation (4) as reconstructed by the model calculations for $26.7 \gamma$. (a) The upper row shows values along the ship track for the $\mathrm{W}-\mathrm{IO}\left(40^{\circ} \mathrm{E}-55^{\circ} \mathrm{E}\right)$, and (b) the lower row for the E-IO $\left(82^{\circ} \mathrm{E}-115^{\circ} \mathrm{E}\right)$. From left to right: $\Delta \mathrm{AOU}, \Delta \mathrm{AOU}^{\mathrm{Bio}}$, and $\Delta \mathrm{AOU}^{\mathrm{Phys}}$, all values in $\mu \mathrm{mol} / \mathrm{kg}$.

due to $\mathrm{C}_{\mathrm{ANT}}$ accumulation and increased organic matter production.

[34] Despite that biogeochemical changes are consistent with an increase in the gyre speed, the possibility of a reduction in the export production, cannot be ruled out to explain the AOU decrease. Direct evidence for the global reduction of primary production or chlorophyll is few and based on the analysis of satellite data [Behrenfeld et al., 2006; Gregg et al., 2003, 2005; Antoine et al., 2005; Polovina et al., 2008]. The SAMW found in the W-IO along $32^{\circ} \mathrm{S}$ forms between $40^{\circ}-45^{\circ} \mathrm{S}$ and $50-80^{\circ} \mathrm{E}$ [McDonagh et al., 2005] and presents a TTD age of about 10 years. The analysis by Antoine et al. [2005] compared CZCS (Coastal Zone Color Scanner) (1979-1983) and SeaWiFS (Sea-viewing Wide Field-of-view Sensor) (1998-2002) data. Therefore, their findings at the $\mathrm{W}-\mathrm{IO}$ formation area would be representative of the SAMW found along $32^{\circ} \mathrm{S}$ in 1995 and 2002. They found a slight chlorophyll increase in the formation area of SAMW, disregarding an AOU decrease linked to a decrease in primary production, at least for the 1995-2002 period.

[35] The model results in the left panel of Figure 5a show that the decrease in AOU that we observed on the $26.7 \gamma$ surface between 1987 and 1995 and between 1987 and 2002 in Figure $3 \mathrm{~b}$ is a reflection of a strong positive AOU anomaly in SAMW that lasted from the late 1980s to 1995. The decline in our observations between 1995 and 2002 is due to the development of a negative anomaly.

[36] The decomposition of the AOU changes in Figure 5a corroborates our findings that the AOU decrease is mainly physically driven. The biological term counteracts the physical forcing but its amplitude only weakens the physical forcing, it cannot completely compensate for it. In the late 80 s and early $90 \mathrm{~s}$, strong changes in the physical component were compensated in parts by the biological component. Physical as well as biological influences weakened toward the mid-1990s, resulting in a prolongation of positive AOU anomaly. For the measurements of 2002 the situation had changed to negative physical forcing balanced to about two thirds by the biological component.

[37] Physically driven variability in AOU is mostly due to ventilation processes as can be seen from the modeled barotropic stream function differences in Figure 6. They show negative anomalies in the region of SAMW formation. As negative anomalies are defined counter-clockwise they represent an intensification of the subtropical gyre, leading
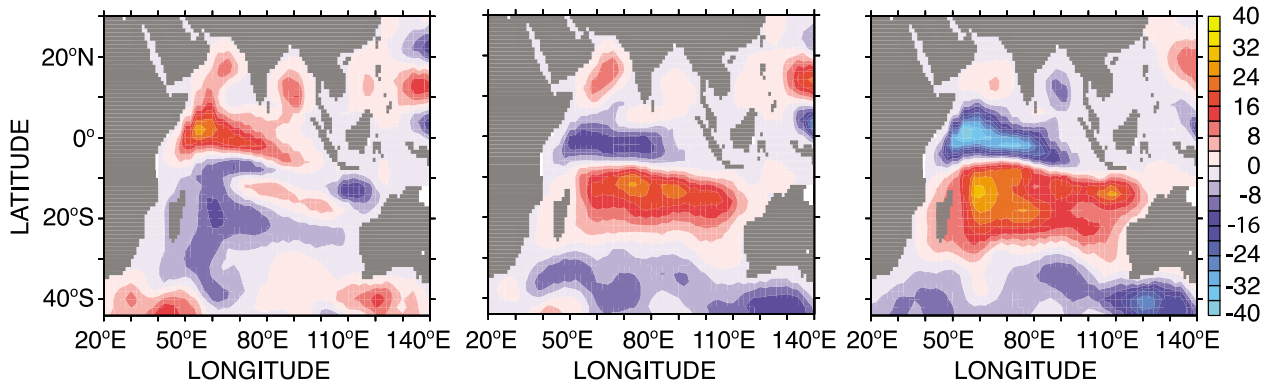

Figure 6. Barotropic stream function differences between (left) 1987 and 1995, (middle) 1987 and 2002 , and (right) 1995 and 2002. Note that negative values are defined counterclockwise and therefore represent an intensification of the counterclockwise subtropical gyre. 
WEST IO

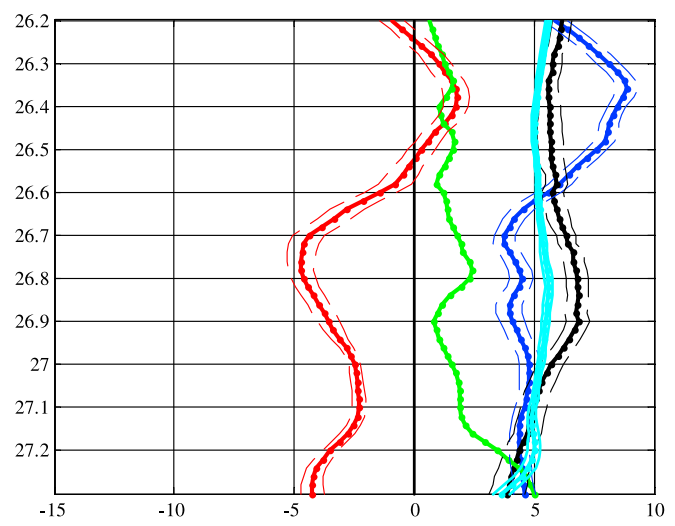

EAST IO

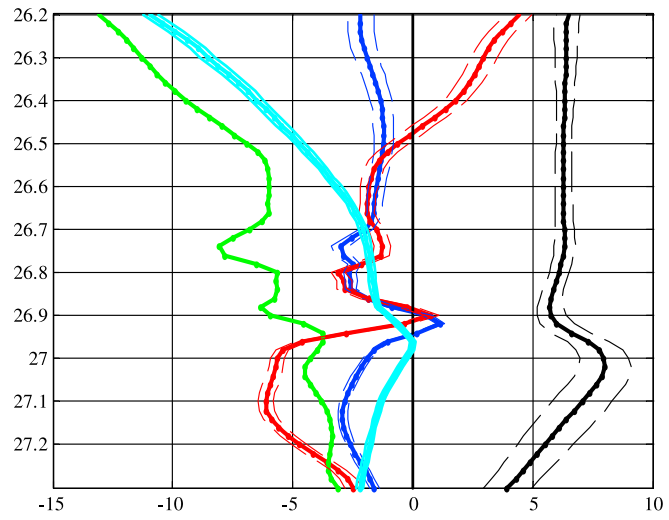

Figure 7. MDP (Mean Difference Profile, solid lines) and SDDP (Standard Deviation Difference Profiles, dotted lines) DIC ( $\left.\mu \mathrm{mol} \mathrm{kg}{ }^{-1}\right)$ changes in the (left) Western $\left(40^{\circ} \mathrm{E}-55^{\circ} \mathrm{E}\right)$ and (right) Eastern IO $\left(82^{\circ} \mathrm{E}-115^{\circ} \mathrm{E}\right)$ between 1995 and 2002 . Changes are calculated on neutral density surfaces. Changes are for 2002 minus 1995. DIC ${ }^{\text {Phys }}$ was calculated with $\mathrm{C}_{\mathrm{ANT}}$ TTD. Dark blue: DIC; Green: DIC Bio; Red: DIC Phys; Light blue: eMLR; Black: $\mathrm{C}_{\mathrm{ANT}}$ TTD.

to increased ventilation and, hence, decreased AOU values for all three periods.

[38] The overall accuracy commonly accepted for DIC measurements is $5 \mu \mathrm{mol} \mathrm{kg}^{-1}$ [Tanhua et al., 2010], which is about the magnitude of the detected DIC changes (Figure 7). The total DIC increase between 1995 and 2002 ( $\triangle$ DIC, dark blue line in Figure 7a) is quite homogeneous around $5 \mu \mathrm{mol}$ $\mathrm{kg}^{-1}$ for neutral densities higher than 26.6, with a mean value of $4.1 \pm 0.3 \mu \mathrm{mol} \mathrm{kg}^{-1}$ (Table 2) in the 26.65-26.85 range, and higher values in the upper thermocline. For waters below 26.6, $\Delta \mathrm{DIC}^{\mathrm{Bio}}$ is negative (Figure $7 \mathrm{a}$ and Table 2 ), with a minimum in the SAMW layer. $\triangle$ DIC $^{\text {CANT }}$ between 1995 and 2002 was obtained from two different methods TTD and eMLR, ranging around $6 \mu \mathrm{mol} \mathrm{kg}^{-1}$ (Table 2) and with very similar vertical distributions (Figure 7a). The similarity between $\mathrm{C}_{\mathrm{ANT}}$ from TTD and eMLR methods for young waters was already obtained and discussed by Matear and McNeil [2003] for the Pacific sector of the Southern Ocean. Physical changes not correlated with $\operatorname{AOU}\left(\Delta D I C^{\text {Phys }}\right)$, either calculated with $\triangle \mathrm{DIC} \mathrm{CANT}^{\mathrm{CAN}}$ from the TTD or the eMLR approach, would be positive and less than $5 \mu \mathrm{mol} \mathrm{kg}^{-1}$ for the studied density range.

[39] The magnitude of the total DIC increase within SAMW between 1995 and 2002 is practically equal or even less than the $\mathrm{C}_{\mathrm{ANT}}$ increase which is somehow counterintuitive. This situation was also found by Lo Monaco et al. [2011] in South Indian mode waters between 1985 and 1998-2001, these authors hint to a slow down and/or shift southwards of the subtropical gyre circulation in the area.

[40] Our findings point to a reduction in the gyre circulation which is translated into an apparent reduction in biological remineralization diminishing the inorganic carbon storage in SAMW and contributing to mask the $\mathrm{C}_{\mathrm{ANT}}$ increase. This relationship is in contrast to the situation found in the Pacific Ocean where DIC changes are enhancing the total carbon change [Sabine et al., 2008]. In the Pacific, the AOU increase is due to circulation changes [Mecking et al., 2008] that shift the $26.6 \sigma_{\theta}$ outcrop, at times even preventing the isopycnal from outcropping.

\subsection{Eastern Indian Ocean}

[41] Salinity increased in the E-IO (Figure 4a) between 2002 and 1987 and 1995-1987, with practically no change in 2002-1995. These changes are centered at $26.8\left(11^{\circ} \mathrm{C}\right)$, at higher $\gamma$ levels than the W-IO. The SAMW in the E-IO is situated at higher densities but lower pressures (Figure 2). The practically linear relation between neutral density and any variable starts from 26.8 compared to 26.6 in the W-IO. Consequently, the upper thermocline associated with SAMW (the 26.8 isopycnal is situated at pressures less than $400 \mathrm{dbar}$, Figure 2) in the E-IO is much more affected by recent remineralization processes than the $\mathrm{W}-\mathrm{IO}$, probably masking any interannual biogeochemical changes that are more clearly defined in salinity.

[42] Changes in $\mathrm{AOU}, \mathrm{NO}_{3}$ (Figures $4 \mathrm{~b}$ and $4 \mathrm{c}$ ) and $\mathrm{PO}_{4}$ (not shown) as in salinity (Figure 4a) are not progressive between 1987 and 2002: within the upper thermocline, down to 27, AOU and $\mathrm{NO}_{3}$ have decreased from 1987 to 2002/ 1995, with practically no change between 1995 and 2002 . $\mathrm{SiO}_{2}$ changes are homogeneous in the entire thermocline (Figure 4d) with no extremes, $\mathrm{SiO}_{2}$ decreased from 1987 to 2002/1995. NTA practically kept constant between 1995 and 2002 (Figure 4e). Upper thermocline salinity changes around 26.8 (Figure 4a) are not associated with any significant variation in age (Figure 4f).

[43] The AOU changes that we found in the profiles of Figure $4 \mathrm{~b}$ for all three time-intervals are reflected in the model results in the left panel of Figure 5b. AOU in the second half of the 1980s and the early 1990s is dominated by a positive anomaly that has been gradually weakening toward 1995 and turned into a rather intermittent pattern of positive and negative anomalies afterwards. The cruise in 2002 happens to fall in a period of a very weak AOU anomaly, which explains the absence of a change between 1995 and 2002 in the observations.

[44] The pattern of biology compensating for physical effects that the model results suggest for the $\mathrm{W}-\mathrm{IO}$ is even more intense in the E-IO. The physical forcing in the E-IO is not uniform over the entire cruise track, but shows a high 
variability East of approximately $107^{\circ} \mathrm{E}$, the area off the Australian coast where the hydrographic situation is dominated by the influence of variability associated with the Leeuwin Current.

[45] Surprisingly, DIC changes in the E-IO are completely different from those in the W-IO (Figure 7). DIC changes point to a small reduction in the total DIC content within the upper and lower thermocline SAMW. The eMLR method does not detect any $\mathrm{C}_{\mathrm{ANT}}$ increase within the whole density range studied. The TTD method shows an increase of about $5 \mu \mathrm{mol} \mathrm{kg}{ }^{-1}$ in the upper and lower thermocline, i.e., the concentration of CFCs increased even though the mean age of the water did not change. It seems that the eMLR method is not capable to detect any consistent $\mathrm{C}_{\mathrm{ANT}}$ increase, probably due to the recent remineralization activity; thus, we use the TTD method to calculate $\Delta$ DIC ${ }^{\text {Phys }}$. In the W-IO, a faster transport of SAMW within the gyre implies that less organic matter is remineralized and consequently less DIC is released and less $\mathrm{O}_{2}$ consumed. The situation is different in the E-IO, where total DIC changes are slightly negative and the anthropogenic uptake is masked by the reduction in remineralized DIC (DIC ${ }^{\mathrm{Bio}}$ ) plus physical changes in DIC not correlated with AOU (DIC ${ }^{\text {Phys }}$ ). These physical changes are not related to a salinity increase. Biogeochemical changes in the E-IO SAMW are probably related to changes in the Antarctic Surface Water transported into the E-IO SAMW formation area. As pointed out by McDonagh et al. [2005] physical changes are likely attributed to changes in the equatorward Ekman flux of Antarctic Surface Water driven northward into the formation site of the mode water, around $40^{\circ} \mathrm{S} 90^{\circ} \mathrm{E}$. These changes are supposed to also alter the biogeochemical properties, AOU, nutrients and DIC, finally detected in the E-IO SAMW layer.

\section{Summary and Conclusions}

[46] This work evaluates the changes in TTD age and biogeochemical properties (AOU and inorganic nutrients) between 1987, 1995 and 2002 in the western and eastern subtropical IO within the SAMW layer. Special emphasis was placed on AOU because of the existing high precision measurements, data availability and sensitivity to biological and physical processes. Additionally, inorganic carbon and alkalinity changes were studied between 1995 and 2002 . The study of decadal changes in inorganic carbon will help to predict the future behavior of the ocean as a carbon sink under changing climatic conditions, both naturally and anthropogenically driven. This work uses the most consistent, accurate and precise $\mathrm{CO}_{2}$ data for the subtropical IO available at the time and discusses the, although small, contrasting trends found on both sides of the gyre.

[47] The increasing trend in salinity and decreasing trend in oxygen from 1960 to 1987 [Bindoff and McDougall, 2000] have reversed between 1987 and 2002 [McDonagh et al., 2005]. Twenty-first century changes within SAMW present a multidecadal oscillation and interannual variability where anthropogenic effects are difficult to discern [Bryden et al., 2003; Murray et al., 2007; Stark et al., 2006]. SAMW properties are the combination of direct air-sea heat and fresh water exchange in the formation area, the Subantarctic Zone, and the Ekman transport of Antarctic Surface Water into the SAZ. Both processes seem to be ultimately related to the Southern Annular Mode modifying the wind strength and pattern within the Southern Ocean [Aoki et al., 2005; Cai, 2006; Thompson and Solomon, 2002].

[48] McDonagh et al. [2005] ascribed the detected salinity changes between 1987 and 2002 to an increased net heat flux in the formation area of W-IO SAMW, around $70^{\circ} \mathrm{E}$ $40^{\circ} \mathrm{S}$. Oxygen and $\mathrm{NO}_{3}$ changes are attributed to an increase in the gyre speed (equivalent to less organic matter remineralization, under a constant primary production assumption), between 1987 and 2002, as indicated by the decrease in TTD age. In the E-IO, upper SAMW has increased salinity from 1987 to $1995 / 2002$, oxygen and $\mathrm{NO}_{3}$ changes are less clear than in the $\mathrm{W}-\mathrm{IO}$ but also point to an oxygen increase $/ \mathrm{NO}_{3}$ decrease from 1987 to 2002 . These changes are attributed to the variability in the equatorward transport of Antarctic Surface Water advected into the formation region of E-IO SAMW, around $90^{\circ} \mathrm{E}$.

[49] No changes in TA between 1995 and 2002 were detected in the E-IO while the slight decrease $\left.(\sim 4 \mu \mathrm{mol} \mathrm{kg})^{-1}\right)$ in the W-IO SAMW layer is coherent with the reduction in biogenic carbonate dissolution due to a faster subtropical gyre circulation. On both sides of the subtropical gyre, although more apparent in the $\mathrm{W}-\mathrm{IO}$, the reduction in remineralized DIC (DIC ${ }^{\text {Bio }}$, related to AOU) is masking the DIC increase due to anthropogenic uptake. The TTD technique detects the same $C_{\text {ANT }}$ increase $\left(\sim 5 \mu \mathrm{mol} \mathrm{kg}^{-1}\right)$ in both sides, in agreement with the eMLR results for the W-IO. However, this is not the case for the E-IO where the eMLR is invalid in the SAMW layer, which is shallower than 500 dbar in this part of the basin.

[50] Clearly, changes in the SAMW in the western and eastern IO are decoupled, affected by different forcing mechanisms. The underlying reason is to be found in the two different main sites of SAMW formation in the IO, at $40^{\circ} \mathrm{S}-70^{\circ} \mathrm{E}$ and $45^{\circ} \mathrm{S}-90^{\circ} \mathrm{E}$, respectively, which are separated by the existence of an anticyclonic subgyre in the southwest IO, which is limited to the east at around $70^{\circ} \mathrm{E}$ between $30^{\circ}-40^{\circ} \mathrm{S}$ [Stramma and Lutjeharms, 1997]. This subgyre contains the $\gamma=26.8\left(13^{\circ} \mathrm{C}\right)$ SAMW.

[51] Changes in the physical forcing derived from climate trends have a direct impact on the thermohaline characteristics of SAMW, but also impact the ocean biogeochemistry: oxygen, nutrients and inorganic carbon. For carbon, the anthropogenic load increase can be masked by climate related trends. The challenge is to identify and quantify the different processes altering biogeochemistry in the ocean, especially in the case of carbon. Very recent biogeochemical data, including $\mathrm{CO}_{2}$, within the subtropical IO will be soon available to confirm whether the trends presented in this work are maintained or reversed. Hopefully a coherent picture about the decadal surface and interior $\mathrm{CO}_{2}$ changes in the subtropical IO will emerge combining data and model simulations [Le Quéré et al., 2007; Metzl, 2009]. We emphasize the need to maintain a sustained and coordinated spatiotemporal observation program for the ocean physical and biogeochemical state using an optimized series of platforms, time series, repeat hydrography, buoys and VOS (Volunteer Observing Ships).

[52] Acknowledgments. Our gratitude goes to the chief scientists, scientists, and crew who participated and put their effort in the oceanographic 
cruises utilized in this study, particularly to those responsible for the carbon, $\mathrm{CFC}$, and nutrients measurements. The fieldwork aboard RRS Charles Darwin along $32^{\circ} \mathrm{S}$ in the Indian Ocean in 2002 was supported principally by the UK Natural Environment Research Council under Grant NER/A/S/ 2000/00438 and under the Core Strategic Research Project Ocean Variability and Climate. M.A. was funded by grant RYC-2006-001836. We would also like to thank Scott Doney and Ivan Lima of the Woods Hole Institution for Oceanography for making the model code available and their support during the execution of the model runs. This is a MALASPINA contribution (CONSOLIDER-Ingenio CSD2008-00077).

\section{References}

Álvarez, M., et al. (2009), Estimating the storage of anthropogenic carbon in the subtropical Indian Ocean: A comparison of five different approaches, Biogeosciences, 6, 681-703, doi:10.5194/bg-6-681-2009.

Andreev, A., and M. Kusakabe (2001), Interdecadal Variability in Dissolved Oxygen in the Intermediate Water Layer of the Western Subarctic Gyre and Kuril Basin (Okhotsk Sea), Geophys. Res. Lett., 28(12), 2453-2456, doi:10.1029/2000GL012688.

Andreev, A., and S. Watanabe (2002), Temporal changes in dissolved oxygen of the intermediate water in the subarctic North Pacific, Geophys. Res. Lett., 29(14), 1680, doi:10.1029/2002GL015021.

Antoine, D., A. Morel, H. R. Gordon, V. F. Banzon, and R. H. Evans (2005), Bridging ocean color observations of the 1980 s and $2000 \mathrm{~s}$ in search of long-term trends, J. Geophys. Res., 110, C06009, doi:10.1029/2004JC002620.

Aoki, S., N. L. Bindoff, and J. A. Church (2005), Interdecadal water mass changes in the Southern Ocean between $30^{\circ} \mathrm{E}$ and $160^{\circ} \mathrm{E}$, Geophys. Res. Lett., 32, L07607, doi:10.1029/2004GL022220.

Banks, H., and R. Wood (2002), Where to look for anthropogenic climate change in the ocean, J. Clim., 15, 879-891, doi:10.1175/1520-0442 (2002)015<0879:WTLFAC $>2.0 . C O ; 2$.

Banks, H. T., R. A. Wood, J. M. Gregory, T. C. Johns, and G. S. Jones (2000), Are observed decadal changes in intermediate water masses a signature of anthropogenic climate change?, Geophys. Res. Lett., 27(18), 2961-2964, doi:10.1029/2000GL011601.

Behrenfeld, M. J., R. T. O’Malley, D. A. Siegel, C. R. McClain, J. L. Sarmiento, G. C. Feldman, A. J. Milligan, P. G. Falkowski, R. M. Letelier, and E. S. Boss (2006), Climate-driven trends in contemporary ocean productivity, Nature, 444, 752-755, doi:10.1038/nature05317.

Benson, B.B., and D. Krause Jr. (1984), The concentration and isotopic fractionation of oxygen dissolved in freshwater and seawater in equilibrium with the atmosphere, Limnol. Oceanogr., 29, 620-632, doi:10.4319/ lo.1984.29.3.0620.

Bindoff, N. L., and T. J. McDougall (2000), Decadal changes along an Indian Ocean section at $32^{\circ} \mathrm{S}$ and their interpretation, J. Phys. Oceanogr. $30(6), 1207-1222$, doi: $10.1175 / 1520-0485(2000) 030<1207$ : DCAAIO $>2.0 . \mathrm{CO} ; 2$

Bindoff, N. L., et al. (2007), Observations: Oceanic climate change and sea level, in Climate Change 2007: The Physical Science Basis: Contribution of Working Group I to the Fourth Assessment Report on the Intergovernmental Panel on Climate Change, edited by S. Solomon et al., chap. 5, pp. 385-432, Cambridge Univ. Press, Cambridge, U. K.

Briegleb, B., et al. (2004), Scientific description of the sea ice component in the community climate system model, version 3, Tech. Note NCAR/ TN-463+STR, 78 pp., Natl. Cent. for Atmos. Res., Boulder, Colo.

Bryden, H. L., E. L. McDonagh, and B. A. King (2003), Changes in ocean water mass properties: Oscillations or trends?, Science, 300(5628), 2086-2088, doi:10.1126/science.1083980.

Cai, W. (2006), Antarctic ozone depletion causes an intensification of the Southern Ocean super-gyre circulation, Geophys. Res. Lett., 33, L03712, doi:10.1029/2005GL024911.

Doney, S. C., et al. (2004), Evaluating global ocean carbon models: The importance of realistic physics, Global Biogeochem. Cycles, 18, GB3017, doi:10.1029/2003GB002150.

Doney, S. C., K. Lindsay, I. Fung, and J. John (2006), Natural variability in a stable, 1000-yr global coupled climate-carbon cycle simulation, J. Clim., 19(13), 3033-3054, doi:10.1175/JCLI3783.1.

Doney, S. C., I. Lima, J. K. Moore, K. Lindsay, M. J. Behrenfeld, T. K. Westberry, N. Mahowald, D. M. Glover, and T. Takahashi (2009a), Skill metrics for confronting global upper ocean ecosystem-biogeochemistry models against field and remote sensing data, J. Mar. Syst., 76, 95-112, doi:10.1016/j.jmarsys.2008.05.015.

Doney, S. C., I. Lima, R. A. Feely, D. M. Glover, K. Lindsay, N. Mahowald, J. K. Moore, and R. Wanninkhof (2009b), Mechanisms governing interannual variability in upper-ocean inorganic carbon system and air-sea $\mathrm{CO}_{2}$ fluxes: Physical climate and atmospheric dust, Deep Sea Res., Part II, 56, 640-655, doi:10.1016/j.dsr2.2008.12.006.

Donohue, K. A., and J. M. Toole (2003), A near-synoptic survey of the southwest Indian Ocean, Deep Sea Res., Part II, 50, 1893-1931, doi:10.1016/S0967-0645(03)00039-0.

Emerson, S., S. Mecking, and J. Abell (2001), The biological pump in the subtropical North Pacific Ocean: Nutrient sources, Redfield ratios, and recent changes, Global Biogeochem. Cycles, 15, 535-554, doi:10.1029/ 2000GB001320.

Emerson, S., Y. W. Watanabe, T. Ono, and S. Mecking (2004), Temporal trends in apparent oxygen utilization in the upper pycnocline of the North Pacific: 1980-2000, J. Oceanogr., 60, 139-147, doi:10.1023/B: JOCE.0000038323.62130.a0.

Friis, K., A. Körtzinger, J. Pätsch, and D. W. R. Wallace (2005), On the temporal increase of anthropogenic $\mathrm{CO}_{2}$ in the subpolar North Atlantic, Deep Sea Res., Part I, 52, 681-698, doi:10.1016/j.dsr.2004.11.017.

Garcia, H., A. Cruzado, L. Gordon, and J. Escanez (1998), Decadal-scale chemical variability in the subtropical North Atlantic deduced from nutrient and oxygen data, J. Geophys. Res., 103, 2817-2830, doi:10.1029/ 97JC03037.

Gent, P. R., and J. C. McWilliams (1990), Isopycnal mixing in ocean circulation models, J. Phys. Oceanogr., 20, 150-155, doi:10.1175/15200485(1990)020<0150:IMIOCM > 2.0.CO;2.

Gregg, W. W., M. E. Conkright, P. Ginoux, J. E. O’Reilly, and N. W. Casey (2003), Ocean primary production and climate: Global decadal changes, Geophys. Res. Lett., 30(15), 1809, doi:10.1029/2003GL016889.

Gregg, W. W., N. W. Casey, and C. R. McClain (2005), Recent trends in global ocean chlorophyll, Geophys. Res. Lett., 32, L03606, doi:10.1029/ 2004GL021808

Gruber, N., K. Keller, and R. M. Key (2000), What story is told by oceanic tracer concentrations?, Science, 290, 455-456, doi:10.1126/science. 290.5491 .455

Gruber, N., S. C. Doney, S. T. Emerson, D. Gilbert, T. Kobayashi, A. Körtzinger, G. C. Johnson, K. S. Johnson, S. C. Riser, and O. Ulloa (2007), The Argo-Oxygen Program: A white paper to promote the addition of oxygen sensors to the international Argo Float program, version 5-1, report, Argo Steering Comm., Paris

Johnson, G. C., and N. Gruber (2007), Decadal water mass variations along $20^{\circ} \mathrm{W}$ in the northeastern Atlantic Ocean, Prog. Oceanogr., 73, 277-295, doi:10.1016/j.pocean.2006.03.022.

Joos, F., G.-K. Plattner, T. F. Stocker, A. Körtzinger, and D. W. R. Wallace (2003), Trends in marine dissolved oxygen: Implications for ocean circulation changes and the carbon budget, Eos Trans. $A G U, 84(21), 197$, doi:10.1029/2003EO210001.

Keeling, R. F., and H. E. Garcia (2002), The change in oceanic $\mathrm{O}_{2}$ inventory associated with recent global warming, Proc. Natl. Acad. Sci. U. S. A. 99, 7848-7853, doi:10.1073/pnas.122154899.

Keeling, R. F., A. Körtzinger, and N. Gruber (2010), Ocean deoxygenation in a warming world, Annu. Rev. Mar. Sci., 2, 199-229, doi:10.1146 annurev.marine.010908.163855.

Key, R. M., A. Kozyr, C. L. Sabine, K. Lee, R. Wanninkhof, J. Bullister, R. A. Feely, F. Millero, C. Mordy, and T.-H. Peng (2004), A global ocean carbon climatology: Results from GLODAP, Global Biogeochem. Cycles, 18, GB4031, doi:10.1029/2004GB002247.

Körtzinger, A., J. I. Hedges, and P. D. Quay (2001), Redfield ratios revisited: Removing the biasing effect of anthropogenic $\mathrm{CO}_{2}$, Limnol. Oceanogr., 46, 964-970, doi:10.4319/1o.2001.46.4.0964.

Körtzinger, A., S. C. Riser, and N. Gruber (2006), Oceanic oxygen: The oceanographer's canary bird of climate change, ARGO Newsl., 7, 2-3.

Large, W. G., J. C. McWilliams, and S. C. Doney (1994), Oceanic vertical mixing: A review and a model with a nonlocal boundary layer parameterization, Rev. Geophys., 32, 363-403, doi:10.1029/94RG01872.

Le Quéré, C., et al. (2007), Saturation of the Southern ocean $\mathrm{CO}_{2}$ sink due to recent climate change, Science, 316, 1735-1738, doi:10.1126/ science. 1136188 .

Li, Y.-H., and T.-H. Peng (2002), Latitudinal change of remineralization ratios in the oceans and its implication for nutrient cycles, Global Biogeochem. Cycles, 16(4), 1130, doi:10.1029/2001GB001828.

Lo Monaco, C., N. Metzl, A. Poisson, C. Brunet, and B. Schauer (2005), Anthropogenic $\mathrm{CO}_{2}$ in the Southern Ocean: Distribution and inventory at the Indian-Atlantic boundary (World Ocean Circulation Experiment line I6), J. Geophys. Res., 110, C06010, doi:10.1029/2004JC002643.

Lo Monaco, C., et al. (2010), Assessing internal consistency of the CARINA database in the Indian sector of the Southern Ocean, Earth Syst. Sci. Data, 2, 51-70, doi:10.5194/essd-2-51-2010.

Lo Monaco, C., N. Metzl, and A. Lenton (2011), Observed changes in dissolved inorganic carbon in mode waters: The interplay between anthropogenic $\mathrm{CO}_{2}$ uptake and ocean variability, SOLAS News, 12, 6-7. 
Matear, R. J., and B. I. McNeil (2003), Decadal accumulation of anthropogenic $\mathrm{CO}_{2}$ in the Southern Ocean: A comparison of CFC-age derived estimates to multiple-linear regression estimates, Global Biogeochem. Cycles, 17(4), 1113, doi:10.1029/2003GB002089.

Matear, R., A. Hirst, and B. McNeil (2000), Changes in dissolved oxygen in the Southern Ocean with climate change, Geochem. Geophys. Geosyst., 1(11), 1050, doi:10.1029/2000GC000086.

McCartney, M. S. (1977), Subantarctic Mode Water, Deep Sea Res., 24, Suppl., 103-119.

McCartney, M. S. (1982), The subtropical recirculation of Mode Waters, J. Mar. Res., 40, Suppl., 427-464.

McDonagh, E. L., H. L. Bryden, B. A. King, R. J. Sanders, S. A. Cunningham, and R. Marsh (2005), Decadal changes in the south Indian Ocean thermocline, J. Clim., 18, 1575-1590, doi:10.1175/JCLI3350.1.

Mecking, S., M. J. Warner, and J. L. Bullister (2006), Temporal changes in pCFC-12 ages and AOU along two hydrographic sections in the eastern subtropical North Pacific, Deep-Sea Res., Part I, 53(1), 169-187, doi:10.1016/j.dsr.2005.06.018.

Mecking, S., C. Langdon, R. A. Feely, C. L. Sabine, C. A. Deutsch, and D.-H. Min (2008), Climate variability in the North Pacific thermocline diagnosed from oxygen measurements: An update based on the U.S CLIVAR/ $\mathrm{CO}_{2}$ repeat hydrography cruises, Global Biogeochem. Cycles, 22, GB3015, doi:10.1029/2007GB003101.

Metzl, N. (2009), Decadal increase of oceanic carbon dioxide in the Southern Indian Ocean surface waters (1991-2007), Deep Sea Res., Part II, 56, 607-619, doi:10.1016/j.dsr2.2008.12.007.

Moore, J. K., S. C. Doney, and K. Lindsay (2004), Upper ocean ecosystem dynamics and iron cycling in a global three-dimensional model, Global Biogeochem. Cycles, 18, GB4028, doi:10.1029/2004GB002220.

Murray, R. J., N. L. Bindoff, and C. J. C. Reason (2007), Modeling decadal changes on the Indian Ocean section 15 at $32^{\circ} \mathrm{S}$, J. Clim., 20, 3106-3130, doi:10.1175/JCLI4160.1.

Ono, T., et al. (2001), Temporal increases of phosphate and apparent oxygen utilization in the subsurface waters of western subarctic Pacific from 1968 to 1998, Geophys. Res. Lett., 28(17), 3285-3288, doi:10.1029/ 2001GL012948.

Pahlow, M., and U. Riebesell (2000), Temporal trends in deep ocean Redfield ratios, Science, 287(5454), 831-833, doi:10.1126/science.287.5454.831.

Palmer, M. H., H. L. Bryden, J. L. Hirschi, and J. Marotzke (2004), Observed changes in the South Indian Ocean gyre circulation, 1987-2002, Geophys. Res. Lett., 31, L15303, doi:10.1029/2004GL020506.

Polovina, J. J., E. A. Howell, and M. Abecassis (2008), Ocean's least productive waters are expanding, Geophys. Res. Lett., 35, L03618, doi:10.1029/ 2007GL031745.

Sabine, C. L., and T. Tanhua (2010), Estimation of anthropogenic $\mathrm{CO}_{2}$ inventories in the ocean, Annu. Rev. Mar. Sci., 2, 175-198, doi:10.1146/ annurev-marine-120308-080947.

Sabine, C. L., R. A. Feely, F. J. Millero, A. G. Dickson, C. Langdon, S. Mecking, and D. Greeley (2008), Decadal changes in Pacific carbon, J. Geophys. Res., 113, C07021, doi:10.1029/2007JC004577.

Sarma, V. V. S. S., T. Ono, and T. Saino (2002), Increase of total alkalinity due to shoaling of aragonite saturation horizon in the Pacific and Indian Oceans: Influence of anthropogenic carbon inputs, Geophys. Res. Lett., 29(20), 1971, doi:10.1029/2002GL015135.

Sarmiento, J. L., N. Gruber, M. A. Brzezinski, and J. P. Dunne (2004), High-latitude controls of thermocline nutrients and low latitude biological productivity, Nature, 427, 56-60, doi:10.1038/nature02127.

Schaffer, G., O. Leth, O. Ulloa, J. Bendtsen, G. Daneri, V. Dellarossa, S. Hormazabal, and P. I. Sehlstedt (2000), Warming and circulation change in the eastern South Pacific Ocean, Geophys. Res. Lett., 27, 1247-1250, doi:10.1029/1999GL010952.

Smith, R., and P. Gent (2004), Reference manual for the Parallel Ocean Program (POP), Tech. Rep. LAUR-02-2484, Los Alamos Natl. Lab., Los Alamos, N. M.
Stark, S., R. A. Wood, and H. T. Banks (2006), Reevaluating the Causes of Observed Changes in Indian Ocean Water Masses, J. Clim., 19(16), 4075-4086, doi:10.1175/JCLI3845.1.

Stramma, L., and J. Lutjeharms (1997), The flow field of the subtropical gyre of the South Indian Ocean, J. Geophys. Res., 102(C3), 5513-5530, doi:10.1029/96JC03455.

Stramma, L., G. C. Johnson, J. Sprintall, and V. Mohrholz (2008), Expanding oxygen-minimum zones in the tropical oceans, Science, 320, 655-658, doi: $10.1126 /$ science. 1153847 .

Stramma, L., M. Visbeck, P. Brandt, T. Tanhua, and D. W. R. Wallace (2009), Deoxygenation in the oxygen minimum zone of the eastern tropical North Atlantic, Geophys. Res. Lett., 36, L20607, doi:10.1029/ 2009GL039593.

Talley, L. D., and M. O. Baringer (1997), Preliminary results from WHP Sections I8N/I5E in the Central Indian Ocean, Geophys. Res. Lett., 24(22), 2789-2792, doi:10.1029/97GL02657.

Tanhua, T., A. Körtzinger, K. Friis, D. W. Waugh, and D. W. R. Wallace (2007), An estimate of anthropogenic $\mathrm{CO}_{2}$ inventory from decadal changes in oceanic carbon content, Proc. Natl. Acad. Sci. U. S. A., 104, 3037-3042, doi:10.1073/pnas.0606574104.

Tanhua, T., D. W. Waugh, and D. W. R. Wallace (2008), Use of $\mathrm{SF}_{6}$ to estimate anthropogenic $\mathrm{CO}_{2}$ in the upper ocean, J. Geophys. Res., 113, C04037, doi:10.1029/2007JC004416.

Tanhua, T., S. van Heuven, R. M. Key, A. Velo, A. Olsen, and C. Schirnick (2010), Quality control procedures and methods of the CARINA database, Earth Syst. Sci. Data, 2, 35-49, doi:10.5194/essd-2-35-2010.

Thompson, D. W. J., and S. Solomon (2002), Interpretation of recent Southern Hemisphere climate change, Science, 296, 895-899, doi:10.1126/science. 1069270 .

Toole, J. M., and B. A. Warren (1993), A hydrographic section across the subtropical South Indian Ocean, Deep Sea Res., Part II, 40(10), 1973-2019.

Wanninkhof, R. (1992), Relationship between wind speed and gas exchange over the ocean, J. Geophys. Res., 97, 7373-7382, doi:10.1029/92JC00188.

Watanabe, Y. W., et al. (2001), Probability of a reduction in the formation rate of the subsurface water in the North Pacific during the 1980s and 1990s, Geophys. Res. Lett., 28(17), 3289-3292, doi:10.1029/ 2001GL013212.

Waugh, D. W., T. W. N. Haine, and T. M. Hall (2004), Transport times and anthropogenic carbon in the subpolar North Atlantic Ocean, Deep Sea Res., Part I, 51, 1475-1491.

Waugh, D. W., T. M. Hall, B. I. McNeil, R. Key, and R. J. Matear (2006), Anthropogenic $\mathrm{CO}_{2}$ in the oceans estimated sing transit time distributions, Tellus, Ser. B, 58, 376-389.

Whitney, F. A., H. J. Freeland, and M. Robert (2007), Persistently declining oxygen levels in the interior waters of the eastern subarctic Pacific, Prog. Oceanogr., 75, 179-199, doi:10.1016/j.pocean.2007.08.007.

Zhang, J.-Z., C. W. Mordy, L. I. Gordon, A. Ross, and H. E. Garcia (2000), Temporal trends in deep ocean Redfield ratios, Science, 289, 1839, doi:10.1126/science.289.5486.1839a.

M. Álvarez, Instituto Español de Oceanografía, Apdo. 130, E-15008 A Coruña, Spain. (marta.alvarez@co.ieo.es)

H. Brix, Department of Atmospheric and Oceanic Sciences, University of California, 5845 Slichter Hall, Los Angeles, CA 90095-1567, USA.

H. L. Bryden and E. L. McDonagh, NOCS, University of Southampton, Waterfront Campus, Empress Dock, Southampton SO14 3ZH, UK.

C. Lo Monaco and N. Metzl, LOCEAN/IPSL, Université Paris 6, place Jussieu 4, F-75252 Paris CEDEX 05, France.

T. Tanhua, IFM-GEOMAR, Düsternbrooker Weg 20, D-24105 Kiel, Germany. 